\title{
Nationalising the International Crime Genre
}

\author{
John Sundholm \& Pekka Vartiainen
}

This article discusses 'transnational' TV, i.e. how to make a national program in a genre and practice seen as an international phenomenon. We believe that such an aspect is often neglected, and that it is important because an international view is impossible in itself. The starting point must be the local to acknowledge from which place you are looking, talking and writing. To assume the global in the first place, as in so many Anglo-Saxon discourses, is to construct a transgressive and mythical view, which only enforces the local. Thus, it is only by acknowledging the local and the national that the international can be produced, discussed, viewed and compared.

We will attempt this by using as our material a Finnish crime serial from 1983 and posing the questions: How to re-make and appropriate a genre that has been represented as transnational; How to translate it to constitute a part of the local culture. Such questions can, however, never be answered from a strictly external perspective, i.e. studying the reception and its relation to the cultural text itself. The text must also be considered in relation to local cultural practice; in its relation to the genre and present values and meanings. This means that we will also perform a close analysis of the crime genre's semiotics in relation to our subject. We begin with the notion of the crime genre and its relation to the series/serial before introducing our subject and the presentation of the questions it raises:

Litteraturvetenskapliga institutionen, Abo Akademi, Nunnegatan 4,FIN-20500Abo,j.sundholm@abo.fi

Department of Comparative Literature, Henrikinkatu 2, FIN-20014 Turun Yliopisto, pekka.vartiainen@pp.inet.fi
The function and meaning of crime and the question of identity, and the relation of the serial to different transnational models.

\section{The Crime Genre}

The crime genre series/serial is one of the most popular forms of drama and entertainment on television. The series (a stable set of characters in different episodes) and serial (a plot developing over several episodes) are also often seen as typical forms of aesthetics for TV and as constituting one of its primary commodities (Ellis 1982, p. 1).

The popularity of the crime genre is often explained by referring to its fundamental social and public character. While the serial and series are perfect forms for investment in a media said to depend on the segment as the narrative structure and repetition as the narrative unit. A segment is a short sequence of drama, which supports the series/ serial because the latter also function as segments in relation to the series or serial as a whole. Furthermore, if the single episodes are numerous, the more obvious is the overall structure as consisting of repeated segments. Such a structure supports, as well, the view of genre as a "social contract" between producer and reader in order to secure proper use of it (Jameson 1981, p. 106), or as simply constituting a "frame for deciphering" (Brown 1992, p. 146).

Consequently, a structure that is repeated is turned into an object because it is easy to recognise the pattern and it can be comfortably institutionalised and materialised in the daily TV programme schedules as well as the scheme of TV production. In fact, the narrative structure of the series/serial is very close to the classical Hollywood film narrative that aimed at creating a coherence of time and 
space (Bordwell 1985). Such a coherence supported an economy of both consumption and production, i.e. the scene is turned into an individual narrative and object, and when the story is filmed it is possible to shoot all the scenes in the same settings at the same time (regardless of their actual place in the story), which saves time and therefore money as well. ${ }^{1}$

But a genre is also "a definition of the world" from a hermeneutic point of view (Brown, p. 146). Fredric Jameson adheres to such a perspective and points out that the detective, as an agent and figure, is 'the social detective' "securing the presupposition of some common world shared by the knower and doer" (Jameson 1992, p. 36), whereas Peter Brooks sees the detective story as a master narrative in its very narrative technique: the narrative constitutes an ars poetica, "using the plot of the inquest to find, or construct, a story of the crime which will offer just those features necessary to the thematic coherence we call a solution, while claiming, of course, that the solution has been made necessary by the crime" (Brooks 1992, p. 29).

Hence, according to Jameson and Brooks, the crime story is a mode for a society to thematize and negotiate its values and meanings. It has a social function, both because of its narrative technique and the way it promotes its protagonist. The detective is an exemplary figure because of her/his unique ability to move and negotiate between the private and the public. The detective, like the doctor, has permission and 'licence' to investigate private rooms in order to be able to protect public interest. In this sense the detective can be seen as the agent that gives its society meaning by negotiating and mediating between the private and the public as well as tracking down the crimes, and revealing the faults and flaws of, society. According to this classical mode, the detective is the perfect spokesman for the public sphere in Jürgen Habermas' sense (Habermas 1989). Therefore - although Habermas originally saw the mass media as a force that was destroying the ideal public sphere - the public should feel satisfied whenever the detective appears on TV because that is an indicator that the society in which the detective acts still poses fundamental questions like: What is right and what is wrong; Which acts are still meaningful; and What should be included and excluded in society.

However, such characteristics for the crime genre in theory are changed and modified whenever they are actualised and materialised in a story, in both medium and specific time and space. Television is especially problematic because of its heterogeneous and multimodal character. In today's Europe TV is no longer public service TV only, but also cable TV and pay TV. It is, furthermore, audiovisual and both textual and multilingual. Viewed from this situation, John Ellis' aphorism that TV is "the private life of a nation-state" seems somewhat out of date (Ellis, p. 5), and especially so when the European Union and multinational business culture constantly problematise the notion of the national. Of course, the popular core of TV programmes still consists of national programmes in international formats: news, sports, shows and serials (Jääsaari 1996). But TV has also increasingly become a medium where the national meets the international (or transnational), particularly in minor countries like Finland where nearly half of the programmes are foreign and therefore subtitled. TV in such European countries is also experienced as a foreign medium - a machine that speaks several languages and therefore also functions as a medium for 'the international life of a nation-(state)', where the state seems diminishing but not the nation.

From a European point of view (i.e. if Europe is the object that is chosen) such a remark is important because it implies that the significance of a program - and hence its analysis - should also be considered in relation to the tension between the national and international. This case is surprisingly seldom realised in all its complexity in countries big enough to produce the major part of programmes themselves and/or to nationalise and domesticate them by the technique of dubbing. Therefore we have chosen as our starting point to ask how an international genre, such as the crime serial and its structure and themes, are actualised in a national context, and to try to make the argument that the genre of the crime series/serial on TV and in Europe is also connected to - and therefore part of - material (medium specific) and cultural (national vs. international) questions. ${ }^{2}$ As our inquiry subject we are using a Finnish TV serial from 1983, Harjunpää och kalla döden/Harjunpää and cold death. We will also, as David Porter does in his The Pursuit of Crime: Art and Ideology in Detective Fiction (1981), use the term detective fiction as synonymous to crime fiction, i.e. all fiction that is concerned with investigating and solving a crime. With the notion 'the detective' we are therefore referring to either a single person or a team investigating. 


\section{Harjunpää}

Matti Yrjänä Joensuu, the writer and policeman who created the figure of Harjunpää, at the time of the TV serial's 1983 broadcast had written five Harjunpää novels. The Harjunpää phenomenon was new to the Finnish reading public and culture. The crime fiction genre as such had constituted an in ternational genre. Crime fiction referred to an international genre consisting of novels, magazines, TV series and films, but it had never been placed in a national context regarding content. Certainly there had been attempts, but they were not taken seriously. Considering this background it is obvious that when Joensuu wrote his first novel in 1976, Väkivallan virkamies/The Official of Violence, his primary aim was to show that the reality of the police was different from how it was shown on TV (Vartiainen and Sundholm 2000). The novel was written according to the genre of the documentary novel, which was essential for its appreciation. The point is that the detective genre itself signalled internationality and therefore had to be carefully appropriated by a national view. However, the genre as such, the documentary was not in any way "national'; it was mainly apt because of its literary value at the time. New was the fact that the detective was an official, trying to work ordinary office hours. These days most detectives, even ones such as the British Cracker, which has institutionalised both family problems and very personal ones as part of the crime genre, still work without the real pressure of a fixed time schedule. It is as if the heroic nature of the otherwise so degraded detective has moved to her/his possibility to ignore time, which in turn has become one of our primary natural powers (and overcoming time, on the other hand, is what makes something mythic and heroic). ${ }^{3}$

When the serial Harjunpää och kalla döden was launched on public service TV in 1983 the critics questioned whether it could be true that someone had made a Finnish crime serial, and that it was even a good one. ${ }^{4}$ If Joensuu, in his novel, had introduced a new genre to the domestic literary market - and successfully so because both the writer and the detective were very well known in the 1980 s - the producers of the serial had to do the same thing by using another media. But there was also another problem: The novels were written in Finnish but the Swedish-speaking unit of the Finnish public broadcasting company (YLE) made the serial.
Finland has - among others - a Swedish-speaking minority with its own public media. Public service TV broadcasts in both Finnish and Swedish. The classical mimetic problem for Swedish fiction in Finland is that for many people the everyday use of language is in both Swedish and Finnish. According to this, a Finland-Swedish representation should pay attention to the use of both languages. Literature clearly sets limits because the European notion of literature is closely bound to the idea of a national language, literature and culture. From a European perspective the Finnish example is interesting. A minority position (Finnish vs. the big European languages) guarantees that the culture of subtitling is well established (in Finland there are subtitles in Finnish as well as Swedish in the cinema). The flexible use of subtitling makes TV also a textual medium. Consequently, audiovisual media are perfect promoters of a heterogeneous and multilingual culture. The Harjunpää serial underscores this by constantly switching between to the two languages, i.e. the subtitles are not naturalised in one language, but different characters speak different languages and the subtitles are changed according to which language is spoken. Of course, this is an abstract situation and is never the same as concrete one. For Finnish-speaking viewers it is odd that Swedish is the language of the majority in the serial, i.e. the actual constellation is turned upside down. But what is important is that the serial acknowledges the differences and points to such an ideal. This is a model that European audio-visual practice should be aware of so TV would constitute a true public sphere. Hence, TV is a medium where different languages can be represented simultaneously and text should be seen as something that also widens the possibilities for the aesthetics of the audio-visual.

Another local and cultural aspect is that TV culture is not very strong in Finland and average TV viewing is almost one hour less per day when compared to France, Germany, Great Britain, Italy and Spain (Pihanurmi 1996). Consequently Finland is ranked as one of the most literary cultures; it publishes more books per year than any other European country of the same size (Statistical Yearbook of Finland 1996, p. 634). ${ }^{5}$ These are cultural facts that become part of every actualisation of a genre and more so when the crime genre and TV constitute the form and medium. The public already has knowledge about the crime genre as such, but from international series like Derrick (Germany), Inspector Morse (UK) and Hill Street Blues (USA) - 
a knowledge that constitutes the frame and genre, the basis from which to view a specific serial. It is more the setting, the rhythm of the dialogue, the pace of cutting and the camera work that sets the inherent norms for the drama when it is translated into a national context. The simple social fact, i.e. whether a country has enough crime, is insignificant (and in fact Finland, according to some statistics, is the most violent country in the EU, topping the statistics of murder and manslaughter per capita, $S Y F$, p. 626-627). This condition of intertextuality' (i.e. texts and their relations to situated readings and not to an external social fact as such) is also the argument that Bennett and Woollacott make about genre in their book Bond and Beyond:

\begin{abstract}
genres can more usefully be viewed as sets of expectations through which the possibilities of reading are organised. Such expectations /.../ are neither lodged within nor produced by the properties of individual texts or even groups of texts viewed in isolation. (Bennett and Woollacott 1987, p. 81)
\end{abstract}

Therefore it is essential, when moving across national borders, to consider the local reading formation (Bennett's term, ibid. p. 64) of the international genre. In short, what matters is not the local as such (the frequency of crimes in the country), but how the international is appropriated by the local culture. We explore this by focusing on how the crime is motivated and the depiction and construction of the male protagonist's identity in the Harjunpää serial.

\section{Crime}

The crime is the purpose, the telos, of the narrative. It both motivates the story (the investigation) and structures it by driving the story towards a closure (a solution) either by revealing why the crime was committed, or by whom. If this narrative telos is ruptured or questioned, the genre in itself is also reconsidered. As Sherlock Holmes says in the classic Naval Treaty: "The most difficult crime to track is the one which is purposeless" (Doyle 1983, p. 314). Most crime genres are structured around this process of investigation and/or closure. The social crime genre is usually constructed around the process of investigation, the team or the teamwork (from the classic American The Untouchables to the German Tatort or British Cracker, where the team is still necessary although problematised and differentiated). The telos of the story of the team is to show a collective that necessitates itself through the process of investigation. The idea is that every part is equal and indispensable. If not in the beginning of the story, the narrative's aim is to achieve such a situation when the story has ended.

The social crime genre is typical for American culture (one of its founding fathers is Ed McBain and his novels about the 87 th Precinct) and has become widely known through American series like Hill Street Blues and NYPD Blue. The aesthetics of the social crime genre usually aim at documentarism. The equivalence to the single objective shot in McBain's novels - constituting a picture of a letter, a portrait or a file - is in the camera work of a TV serial. In, for example, NYPD Blue, the camera is constantly moving when it is out in the streets, searching for its subjects that seem to never stand still, and when the camera finally finds its target it seems more authentic and objective than if it had been in focus from the beginning.

The European tradition favours the solitary detective, as in A Touch of Frost (UK), Der Alte (Germany) or Anna Holt - polis (Sweden). This is also a literary tradition. The relatively solitary detective is one of the last heroes in modern society, who through investigations is confronted with her/his own identity and self in chasing the criminal-a figure established as a person and not only a (social) character. This psychological model is a common European trait, if seen in opposition to American series and serials where money is the primary motivation and the construction of the psychological portrait of the criminal is of minor importance. In general American popular stories aim at reliability at the level of conflict, where non-American (European) ones aim at creating reliable psychological characters. This is also evident from the stories' settings. In the U.S. the street and the office are essential, whereas European crime genres are more often placed in domestic or even rural settings.

The Finnish serial Harjunpää ja kylmä kuolema is typically European (in the sense that it differs from American mainstream) in both its general structure and setting. It was made in four parts of the usual length for TV programmes of approximately 50 minutes for each episode. The setting is balanced between home and work. A further Scandinavian trait is to concentrate on the family (for example the Swedish Anna Holt series) and small children in particular. They are essential members of a detective's family reality (the British equivalent is usually a family with children in their teens, probably a reminder of the fact that small 
children are integrated into society, and seen as part of the public, at an earlier age in the Nordic countries because of the public day-care system).

The Harjunpää serial tells about a murder committed in the underworld of Finland's capital, Helsinki. It is adapted from Joensuu's third novel about his hero, Harjunpää ja kapteeni karhul Harjunpää and Captain Karhu (1981), with the subtitle: "A novel about a crime, its perpetrators and investigation". The subtitle is essential. It is both a statement that places the narrative according to a documentarian aesthetic (like the typical crime genre opening: a shot that states the exact time and date) and a mini-narrative in itself, which tells us that a crime has occurred and that the story will unfold by moving between committer and investigator.

The serial starts with a body. Hence, the body is made into an empty and purely material sign, which poses the questions: Who and Why. To be able to prolong the story, it is soon revealed that the first body is not the result of a crime. It is simply a woman overrun by a train. But the body launches the investigation and the presentation of the characters so that, when the crime is committed, every face is already familiar. This is essential aesthetics of the audio-visual crime genre. It can very well be described as a struggle with time, with expensive raw material (filmstock, technical equipment, staff, etc.) and strictly scheduled schemes of consumption, which necessitates a fast moving and clearly segmented story. When the real crime is committed the story is already running and all significant faces, bodies and places are familiar.

The crime committed in the serial - and which results in a body - is contingent. An old alcoholic and former captain (Karhu) kills a woman by accident. The captain is a well-meaning man and wants to confess the crime, but the police do not believe an old drunkard. The crime is concealed because the captain has, as his duty, to look after stolen goods, i.e. he is living for free in a basement where the goods are. Because the captain is lonely he spends time with some of the neighbourhood boys, something that his fencer does not like. He says, the women are gossiping already, and tells the captain to give any of them a warning not to sneak around. It is when one of the women comes down to the cellar that the captain decides to warn with a hit. The result is a body.

The body is so evident in all crime genres that we seldom pay attention to it and it has therefore taken over the role of a Hitchcockian McGuffin. ${ }^{6}$ It is the thing, the object that initialises the quest and therefore the story. In this sense the body in itself is meaningless, and the question is instead about into what relations the body can be placed. These relations and connections make up the structure of the story and hence its meanings and values. The strategy is essential for modern thinking; in a way it could be said that the detective is not so much the product of a rational society's longing for meaning as a demonstration of a sociostructural logic and world view (Kracauer 1979). In all crime genres, every person has a history and they all carry these histories within themselves and it is the historical and social situation that determines how these histories are erupted and canalised.

Joensuu adheres to such a narrative ideology in his writing and he has stated that a study by a Finnish scholar in psychology, Liisa KeltikangasJärvinen, has influenced him (Vartiainen and Sundholm). ${ }^{7}$ The motivation of crime in the Harjunpää-serial is chance. The body in Harjunpää's fictional world is very seldom a result of rational calculation; it is not something caused by the object alone. Instead it is a question of when history clashes with the present. According to Keltikangas-Järvinen nearly $50 \%$ of all cases of manslaughter in Finland are not rationally planned, but they are not irrational either. It is the social situation that pulls the trigger; the bullet is the history, meanings and acts that have already been constituted. This view of how crime is motivated is another axis that may serve as an instrument for classifying the crime genre. Is the crime motivated sociologically: By external factors, such as being a result of a criminal subculture or a sudden social change? Or psychologically: By internal factors, such as foregrounding the committer's personal history? This classical opposition between individual and society is of course a fundament of the crime genre and is reflected in how the process of investigation is told; is the agent acting on his own or is (social) agency represented through a team, an investigating collective? The question is important because the crime genre is not only told in relation to the object (the body and the motive behind it) and which the investigating 'subject' is (for example, the team/the private detective or the solitary official) but also in relation to how the investigating subject is constituted in relation to the process of investigation. This is a gap, or space, for the audience's participation. For the detective it is a question of identity, of identifying the body and the motive, a process during which the detective also reflects on his/her identity, thereby also making a space for the audience to intervene (if the story is 
not told from the perspective of the one who has committed the crime).

\section{Identity}

In recent studies it is often claimed that identity must be defined as constituted by a "system of representations and relations", and not as an object in itself (Schlesinger quoted in Morley and Robbins 1995, p. 46). As a concept it traditionally refers to something that is unbiased, or unambiguous. According to such logic, the aim of the detective is to both create and guarantee identity. The investigator creates meaning for the society in which he acts; essential is how the detective moves between the private and public as mediator and agent of meaning. The detective therefore becomes the central character and focal point for investigating how a system of relations is constructed, viewed and represented.

The social crime genre presents a team. The team is usually defending national interests in confrontations with the international (The Professionals) or serving to defend public security and interest inside the nation (Cracker). Crime genre stories focused on a solitary character as the investigator (A Touch of Frost or another British success like Prime Suspect) are able to focus more closely on the relation between personal identity and the social. The evil as such, the criminal act, is an external force that pays attention to where the boundaries are drawn between self and other on a private and public level - what should be integrated into society and what is acceptable behaviour on a personal level.

In the Harjunpää-serial the detective is a state official. He is not well paid and is constantly struggling with money problems. The serial presents many domestic shots, which are part of mindscreens, i.e. he is not physically there. The family is seldom a real place in the serial, but more of an emotional place he remembers and relates his feelings to. This persistent movement between home and work is turned into an opposition that makes it possible to show how he is reflecting on his personal relation to his quest as an official. His job is to defend public interests, to serve the nation - acts that are often questioned when he relates them to his private role as father of two small children. This constellation is important. The ideology of a crime genre serial is very often detectable by the places serving as the real co-ordinates of the story. The classical idealistic genre shows a hero at work all the time, and the opposition is between the of- fice and the street. Such a detective is a pure social character who rarely has a personal identity crisis the identity crisis is that of a society or a nation. The other crime genre stories, those that make use of other and more domestic settings put the crisis at a more personal or internal level. The optimal example is of course crime genres, which are more like mystery series (the American $X$-files or the British Touching Evil), where the confrontation with something radically other and external is a fundamental way for the confronting subject to face itself. Therefore such stories seldom have a closure and clear ending. In the Harjunpää serial it is ultimately a question of confronting male identity. In traditional western society the male role presupposes that he is a public man of action. This is the identity also offered to Harjunpää through his work. But when he must act he seldom has the strength to fulfil the role. In a more socially oriented crime genre such a weakness would be a way to make a collective argument. The hero would be rescued and complemented by the team. Instead an ordinary policeman, shown for the first time in the serial, rescues Harjunpää. This happens during the serial's last scenes. When Harjunpää is heading into a dark cellar to catch the real criminal, the fencer, he is hardly able to break down the door behind which the fencer hides. The scene ends with two unheroic male figures. The dangerous fencer is found drunk and crying and he makes no resistance. The detective is nervous, shaking and has fallen down on the ground when he has attempted to break the door down. From this close-up follows a jump cut to Harjunpää vacuum cleaning at home - an act he is performing without any trouble, suggesting that he is better suited for action at home.

This last scene seems to suggest that the true place for Harjunpää is home. The last return in a narrative is also important for every story of the crime genre. The team always returns to its true working place, the office or police station. This last return is always a foregrounding of which the real place of the social detective is. Place, in this sense, is not only equal to a physical place (office, home, street etc) but also significant in a more fundamental sense. The place that is returned to is made into the social detective's very context - something important, because finding the right context is what the creation of identity and making of meaning is all about.

The argument could even be pushed a bit further. According to the Finnish psychologist Liisa Keltikangas-Järvinen many acts of violence and aggression are caused by a narcissistic pathology 
(Keltikangas-Järvinen 1977). The reason is a weak sense of self and identity on the part of the aggressor. Hence, the problem of narcissism out of control is that the subject feels threatened and acts accordingly. Perhaps the question of the crime genre's popularity is exactly the need for a society to secure its position and self-image, its identity. This need not to be seen as pathologic and the question of narcissism should not been viewed beforehand as something negative. Even a statement such as " $[t]$ he detective story is a fiction of alienation addressed to an experience of anxiety" can be criticised for being exaggerated (Paterson 1995, p. 108). What is at stake is a society's search for meaning - a complex constellation of agents and agency, which include both producer and consumers. Of course, the detective story and the crime genre are ideal modes. They directly confront epistemological questions like making (by recomposing and forming) meaning through identifying and making histories for the objects under investigation, in order also to make a value judgement about what to include and exclude-but only from a strictly theoretical point of view. Every story is materialised in a social situation and in a culture. The Finnish Harjunpää serial, for example, establishes a true Nordic social democratic male hero, whose life the TV viewers follow through different episodes partly because they differ from the international models and, in that sense, from the theoretical genre as such. That difference is always part of a genre; it is the genre materialised in a practice. 14 is an abstract international number, but as a police code in Helsinki it signifies 'death'. Hence, in a very specific context it has a meaning with consequences. But that meaning is only a part of a paradigmatic texture and multiplicity of contexts. One such context - as we have tried to point out - is the tension between the national and international (or transnational). That relation can, however, not be traced without tracking down other paradigmatic textures such as genre, the form of the serial, the medium used, etc. Acknowledging such differences is not only a matter of correct academic practice; it is also a question of value. The international is also a question of approving and paying attention to difference, something that is both a democratic ideal and a way of keeping a space open for agency and change, and interaction in that sense. We believe that the Harjunpää serial therefore functions as an example of local appropriation and interaction between the national and the international and, hence, cultural difference.

Väkivalta ja itsetuho: Miten tuhokäyttäytyminen syntyy, Helsinki: Otava 1978.

\section{References}

Bennett, Tony and Woollacott, Janet (1987) Bond and Beyond: The Political Career of a Popular Hero. London: Macmillan.

Brooks, Peter (1992 (1984)) Reading for the Plot: Design and Intention in Narrative. Cambridge, MA: Harvard University Press.

Bordwell, David (1985) Narration in the Fiction Film. London: Methuen.

Brown, Richard Harvey (1992 (1987)) Society as Text: Essays on Rhetoric, Reason, and Reality. Chicago: University of Chicago Press.

Doyle, Arthur Conan (1983) "The Adventure of the Naval Treaty", The Original Illustrated Sherlock Holmes. Secaucus, NJ: Castle Books.

Ellis, John (1982) Visible Fictions - Cinema: Television: Video. London: Routledge.

Habermas, Jürgen (1989) The Structural Transformation of the Public Sphere. Cambridge, MA: MIT Press. 
Gripsrud, Jostein (1995) The Dynasty Years: Hollywood Television and Critical Media Studies. London: Routledge.

Jameson, Fredric (1981) The Political Unconscious: Narrative as a Socially Symbolic Act. Ithaca: Cornell University Press.

Jameson, Fredric (1992) The Geopolitical Aesthetic: Cinema and Space in the World System. London: BFI.

Joensuu, Matti Yrjänä (1981) Harjunpää ja kapteeni Karhu. Helsinki: Otava.

Jääsaari, Johanna (1996) "Television katsotuimmat ohjelmat suomalaisuuden kuvina", Radio- ja TV-tutkimuksen vuosikirja. Helsinki: YLE

Keltikangas-Järvinen, Liisa (1977) Personality Crisis of Violent Offenders and Suicidal Individuals. Helsinki: Suomalainen Tiedeakatemia.

Kracauer, Siegfried (1979) Der Detektiv-Roman. Frankfurt a M: Suhrkamp.

Morley, David and Robbins, Kevin (1995) Spaces of Identity: Global Media, Electronic Landscapes and Cultural Boundaries. London: Routledge.
Paterson, Richard (1995) "Drama and Entertainment", Television: An International History. Oxford: Oxford University Press.

Pihanurmi, Vesa (1996) "Televisioyleisö 1988-1995”, Radio- ja TV-tutkimuksen vuosikirja. Helsinki: YLE.

Porter, David (1981) The Pursuit of Crime: Art and Ideology in Detective Fiction. New Haven: Yale University Press.

Short, John Rennie (1991) Imagined Country. London: Routledge.

Statistical Yearbook of Finland (1996) Helsinki: Statistics Finland.

Sundholm, John (1999) Populärt berättande och offentlighet: Sujet, Excess, den sociala detektiven och den privata familjen. Åbo: Åbo Akademi University Press.

Vartiainen, Pekka and Sundholm, John (2000) "Se yksinäinen asia", Parnasso:1, Interview with Matti Yrjänä Joensuu, September 1999. 